\title{
O TELEJORNALISMO REGIONAL COMO ESPAÇO PRIVILEGIADO PARA A DIVULGAÇÃO CIENTÍFICA
}

\author{
BÁRBARA MARTINS ZAGANELLI \\ Universidade Federal do Rio de Janeiro (UFRJ) \\ Rio de Janeiro, Brasil \\ E-mail: barbarazaganelli@hotmail.com
}

MARCELO CARLOS GANTOS

Universidade Estadual do Norte Fluminense Darcy Ribeiro Campos dos Goytacazes, Rio de Janeiro, Brasil

E-mail:mgantos@uenf.br 


\section{O TELEJORNALISMO REGIONAL COMO ESPAÇO PRIVILEGIADO PARA A DIVULGAÇÃO CIENTÍFICA}

Resumo: $O$ telejornalismo é um meio de eficiente para o escoamento da produção científica, principalmente, os telejornais regionais que possuem espaços mais promissores para a exibição de pesquisas locais se comparados aos nacionais. Este artigo, com aporte teórico na Hipótese do Agendamento, faz uma reflexão sobre a capacidade que telejornais regionais têm de agendar debates públicos de divulgação científica.

Palavras-chave: Divulgação Científica. Telejornalismo. Cidadania.

\section{LA TELEVISIÓN PERIODISMO REGIONAL COMO UN ESPACIO PRIVI- LEGIADO PARA DIVULGACIÓN CIENTÍFICA}

Resúmen: La noticia la televisión es un medio eficaz de la corriente de la literatura científica los programas de noticias, principalmente regionales que tienen las áreas más prometedoras para la visualización de las búsquedas locales en comparación con los nacionales. En este artículo, con el apoyo teórico en la Hipótesis de programación, es una reflexión sobre la capacidad de los noticieros regionales tienen que programar los debates públicos de la ciencia. Palabras-clave: Comunicación de la ciencia. Noticiero. Ciudadanía.

THE REGIONAL TV JOURNALISM AS A PRIVILEGED SPACE FOR SCIENCE COMMUNICATION

Abstract: The television news is the main information channel of the country is an efficient means of communication for the flow of scientific mainly regional news programs that have the most promising areas for the display of local searches compared to the national news. This article, with theoretical support in the Scheduling Hypothesis, is a reflection on the ability of regional newscasts have to schedule public discussions of science.

Key-words: Science Communication. TV Journalism. Citizenship. 


\section{INTRODUÇÃO}

Em um olhar mais atento, nota-se que o conhecimento científico não chega à grande parte da população. Basta observar as inúmeras dissertações e teses que ficam “intocáveis" sem ganhar a legitimidade do público. Há casos que nem chegam ao conhecimento dos próprios pesquisadores da área. Por isso, é importante que as pesquisas caminhem de mãos dadas com a divulgação científica para que o esforço dos profissionais envolvidos na Ciência, Tecnologia e Inovação (CT\&l) contribua para a qualidade de vida, a inclusão social e o exercício da cidadania de uma camada mais expressiva da sociedade. Como diz o dito popular: "Não basta botar o ovo, tem que cacarejar!".

Este estudo apresenta uma revisão sobre a divulgação científica pelos telejornais regionais. A televisão, e mais especificamente o telejornalismo, reúne atributos que podem ajudar essa empreitada. Os noticiários conseguem potencializar a transformação de assuntos estocados em universidades, faculdades e outras instituições de pesquisa em temas de debates públicos. Mais que isso: como eixo de reflexão social pode influenciar as formas de governo, os estilos de produzir saberes e as maneiras de compreender o mundo.

Essa noção apoiada na Hipótese da Agenda-setting (que explica sobre a capacidade de agendamento que os meios de comunicação têm sobre as agendas públicas e políticas) alerta para a importância da difusão da CT\&l em programas diários, de forma constante e com uma abordagem propícia a elevar o grau de compreensão pública do tema. Wolf (2003) lembra que em função do que se noticia pela mídia, o público "é ciente ou ignora, dá atenção ou descuida, enfatiza ou negligencia elementos específicos dos cenários públicos" (Wolf, 2003; p. 144). O telejornalismo sendo o principal canal informativo do país é, sem dúvida, um meio de comunicação eficiente para o escoamento da produção científica, principalmente, os telejornais regionais que possuem espaços mais promissores para a exibição de pesquisas locais se comparados aos noticiários nacionais.

\section{A DIVULGAÇÃo CIENTÍFICA PARA A FORMAÇÃo DE UMA CULTURA CIENTÍFICA E INCLUSÃO SOCIAL}

O Brasil vive um dos seus melhores momentos de produção científica no cenário internacional. Nas últimas décadas, o país deixou de ser um mero 
observador dos avanços da Ciência, Tecnologia e Inovação (CT\&l) e passou a produzir e a investir mais em pesquisas conseguindo atingir números expressivos de titulação e produção científica. Segundo o Ministério da Ciência e Tecnologia (2011), o Brasil subiu 13 posições no ranking de inovação pelo Indicador Global de Inovação1 2011 (The Global Innovation Index), passando do $60^{\circ}$ lugar, em 2010 , para a $47^{\circ}$ posição.

Já no ranking de produção científica ${ }^{2}$ ocupa atualmente a $13^{\mathrm{a}}$ posição e tem a liderança na América Latina. Em 2010, 50.904 mestres e doutores se formaram, de acordo com a Sociedade Brasileira para o Progresso da Ciência (SBPC), fomentando ainda mais as bases de estudos. Mas embora esse universo seja bastante otimista em relação ao crescimento de pesquisas, tanto em quantidade quanto em qualidade, o mesmo não aconteceu curiosamente em relação ao desenvolvimento social. Para este trabalho, esse descompasso entre o desenvolvimento científico-tecnológico e o desenvolvimento social está vinculado, principalmente, à carência de divulgação científica.

Observa-se que nas universidades e em outras instituições integradas ao sistema nacional de pesquisa, as comunidades científicas ${ }^{3}$ ficam, muitas vezes, isoladas e o conhecimento 4 estocado não chega à população. Essas barreiras na comunicação intensificam-se até mesmo devido às especializações, o rápido desenvolvimento, a sofisticação dos mecanismos e a utilização de uma linguagem própria. Com isso, sem o esforço em prol à divulgação científica, as possibilidades da socialização do conhecimento científico ${ }^{5}$ passam a ser mínimas.

10 ranking é calculado anualmente pelo Insead, uma das principais escolas de negócios da Europa, em parceria com a Organização Mundial de Propriedade Intelectual (Wipo, na sigla em inglês). A agência é ligada à Organização das Nações Unidas (ONU). Disponível no <http://www.mct.gov.br/index.php/content/view/332281.html>. Acesso em: $01 \mathrm{dez} .2012$.

2 Disponível em: <http://www.capes.gov.br/servicos/sala-de-imprensa/36-noticias/ 5263-para-mercadante-desenvolvimento-da-educacao-e-da-ciencia-e-o-maior-desafio-do -brasil>. Acesso em 13 nov. 2012.

3 Bourdieu (2008, p. 67) diz que “(...) Merton orquestra a ideia de <<comunidade >> como o tema do $<<$ comunismo $>>$ dos cientistas como um $<<$ grupo cujos membros estão unidos por um objetivo e por uma cultura comuns $>>$. (...)".

4 GUIMARÃES, E. (2003, p. 21) diz que “(...) falar de conhecimento é falar de sentidos em movimento, de sujeitos e ideias que circulam e como circulam; é considerar os modos de dizer e as relações entre eles, os instrumentos que lhes estão concernidos e os processos de sua institucionalização".

5 Para Bourdieu (2008, p. 101), “o conhecimento científico é aquilo que sobreviveu às objeções e pode resistir às objeções futuras”. 
A divulgação científica, do latim divulgare, significa tornar público ou notório; propagar; publicar; difundir; vulgarizar; torna-se público ou conhecido; propagar-se; difundir-se (FERREIRA, 2004). Authier-Revuz (1998) explica que a divulgação científica consiste em colocar de forma acessível ao grande público o resultado das pesquisas científicas.

A Divulgação Científica é classicamente considerada como uma atividade de disseminação, em direção ao exterior, de conhecimentos científicos já produzidos e em circulação no interior de uma comunidade mais restrita: essa disseminação é feita hora escolar-universitária e não visa à formação de especialistas, isto é, não tem por objetivo estender a comunidade de origem." (AUTHIER-REVUZ, 1998, p.107)

Outro autor, Calvo Hernando (2004) explica que está mais do que claro que os principais objetivos da divulgação científica estão ligados ao conhecimento (que é comunicar ao público os avanços científicos da atualidade) e à ação (a atuação social em relação às consequências que o desenvolvimento científico e tecnológico pode resultar). Mas adiantam que atingi-los não é tão simples. Pereira (2003) conta que a divulgação científica no Brasil estabelece um confronto discursivo diário entre dois estilos de abordagem da informação: um com o enfoque no espetáculo e nas grandes descobertas contemporâneas e o outro mais crítico, tentando distinguir os fatos extraordinários, que acontecem raramente, dos pequenos avanços que ocorrem continuamente.

Reis (2002) alerta que é preciso bem mais que isso. É necessário veicular a Ciência como processo, em uma linguagem simples, mostrando os princípios nela estabelecidos, das metodologias que emprega e apontando, principalmente, a intensidade dos problemas sociais implícitos nessa atividade. Destaca-se ainda que não se trata de uma mera tradução de uma linguagem especializada para a coloquial. Para Sánshez Mora (2003), a divulgação científica precisa criar um elo entre o mundo da Ciência e os outros mundos. Por isso, um dos desafios deste trabalho é traçar estratégias para aproximar esses dois mundos.

Esta pesquisa defende que para que haja a Compreensão Pública da Ciência pela divulgação científica é fundamental que as informações sejam transmitidas de forma clara, simples, direta e de fácil entendimento. Afinal, precisam atingir todas as camadas e faixas etárias da sociedade para de fato serem compreendidas pelo público e assim, simultaneamente, contribuir 
para a desmistificação acerca do tema. Esse compartilhamento promove a sobrevivência da própria ciência ${ }^{6}$.

Medeiros (2003) diz que a divulgação científica consolida e legitima7 a atividade científica, impulsionando o aumento da comunidade científica ${ }^{8}$ e subsidiando decisões acerca dos órgãos que integram o Estado. Motta-Roth (2009a) lembra que a população só apoia, e consequentemente financia as pesquisas, em áreas construídas discursivamente pela mídia como relevantes. Portanto, a divulgação científica deve ser vista como um como uma política pública para a formação da cultura científica e inclusão social.

Se por um lado, a CT\&I são capazes de definir o futuro de um povo, do outro podem ser excludentes ${ }^{9}$ (SANCHS, 2000). Em pleno século XXI, nem todos têm o acesso ao uso dessas ferramentas, o que leva diversas entidades como a UNESCO (2000) a se preocuparem com a exclusão de uma parcela considerável da sociedade ao acesso dos bens tecnológicos criando inclusive conceitos como o de exclusão digital ${ }^{10}$.

No Brasil, percebe-se que a população ainda é carente de informações ligadas à CT\&I desenvolvidas nas universidades e em outras instituições integradas ao sistema de pesquisa nacional. Entende-se que a mola ética propulsora dos cientistas é a melhoria de qualidade de vida da população. Mas para que isso ocorra de fato, as informações sobre os avanços e as descobertas científicas precisam chegar à sociedade contribuindo para a construção de uma cultura científica.

Oliveira, F., (2001) define a cultura científica como a capacidade de responder de forma significativa às questões técnicas que aparecem no coti-

6 Vista como “erudita”.

7 Para Bourdieu (2008, p. 76), “(...) A legitimidade do conhecimento depende de uma presença pública em certas fases da produção do conhecimento”.

8 Bourdieu (2008, p. 67) diz que “(...) Merton orquestra a ideia de <<comunidade > como o tema do <<comunismo $>>$ dos cientistas como um $<<$ grupo cujos membros estão unidos por um objetivo e por uma cultura comuns $>>(. .$.$) ".$

9 Fleury (2002) diz que a exclusão é um processo cultural que implica o estabelecimento de uma norma que proíbe a inclusão de indivíduos, grupos ou populações em uma comunidade.

10 A exclusão digital diz respeito às consequências sociais, econômicas e culturais da distribuição desigual do acesso a computadores e Internet, excluindo-se o acesso à telefonia. Sobre isso, diversos autores, como Silveira (2001) e Mattos (2003), destacam que a exclusão digital chega, em muitos casos, a ampliar o grau de desigualdade social existente em certas sociedades. 
diano e no mundo das ações políticas. É mais do que simplesmente compreender o assunto. É ter um senso crítico sobre o tema para interferir com conhecimento em decisões e ações políticas relacionadas ao tema.

É justamente por isso que Pereira et. al. (2003) acreditam que a cultura científica seja fundamental para o exercício da cidadania e para o estabelecimento de uma democracia" participativa. O treinamento técnico da força de trabalho possibilita a formação de pessoas aptas à compreensão acerca das promessas e ações governamentais e, ao mesmo tempo, eleva a capacidade da população para participar das decisões públicas. Todo o indivíduo deve ser educado cientificamente sobre os aspectos contemporâneos da CT\&l ou ficará sujeito às manipulações daqueles que detêm o conhecimento e controlam suas aplicações (PEREIRA ET.AL., 2003).

Vista dessa maneira, a divulgação científica constitui como um inovador instrumento de inclusão social, considerado esta como um dos grandes desafios do país por motivos históricos. Segundo Moreira (2006), a inclusão social proporciona as populações social e economicamente excluídas ${ }^{12}$ terem oportunidades e condições de ser agregadas à sociedade que pode usufruir desses bens.

Em um sentido mais amplo, a Inclusão Social envolve também o estabelecimento de condições para que todos os habitantes do país possam viver com adequada qualidade de vida e como cidadãos plenos, dotados de conhecimentos, meios e mecanismos de participação política que os capacitem a agir de forma fundamentada e consciente. (MOREIRA, 2006, p.1, grifo nosso).

Embora a principal razão da exclusão referida esteja relacionada à ausência de uma educação científica no ensino fundamental e médio do Brasil,

11 De acordo com Touraine (1996), "não há democracia sem cidadania”. Segundo Bobbio (1986, p.12), o regime democrático pode ser entendido como "um conjunto de regras (primárias ou fundamentais) de procedimentos para a formação de decisões coletivas, em que está prevista e facilitada à participação mais ampla possível dos interessados". Ao contrário do Capitalismo, o autor explica que a democracia privilegia a satisfação do social sob o indivíduo. Mas o conceito de democracia também está longe de ser um corpo orgânico, para Bobbio (1992). O autor argumenta que a democracia é a soma de indivíduos e isso não pode ser separado do conceito de direitos do homem. Uma concepção que vai de encontro ao conceito de cidadania (CARVALHO, J. 2003).

12 No sentido de terem acesso muito reduzido aos bens sejam materiais, educacionais, culturais, entre outros, da média brasileira. 
a divulgação científica é um dos mecanismos mais viáveis que podem ser usados em prol da inclusão. Isso ocorre, pois a divulgação científica tem a possibilidade de criar oportunidades para o público formado por não-especialista de adquirir um conhecimento sobre a Ciência e seu funcionamento, compreender o seu entorno, ampliar suas oportunidades no mercado de trabalho e fazer com que o público consiga discutir com conhecimento de causa os assuntos acerca do tema.

Barros (2003) explica que os programas de difusão surgem como alternativas importantes para cobrir a defasagem entre o saber escolar e os produzidos nos laboratórios e centros de pesquisa e que os colégios não podem dar conta. Além disso, o ensino formal não dá conta da permanente reciclagem que se faz necessária para que um profissional já formado e exercendo as suas funções junto à sociedade possa manter-se inserido no processo de transformação social. Para esta pesquisa, está mais do que evidente a real importância da divulgação científica já que é fundamental ter um nível de conhecimento científico mínimo para poder integrar-se a vida social.

\section{A RELAÇÃo ENTRE A ROtina dos telejornais REgIONAIS E A AGENDA PÚBLICA E POLÍTICA}

Os estudos sobre a questão dos efeitos dos mass media e a maneira como constroem a imagem da realidade social ocupam há décadas um papel relevante nas investigações científicas sobre o jornalismo e as notícias, e de modo geral atravessam o campo da Comunicação Social. Neste trabalho, a investigação sobre os efeitos dos media foi a partir da Hipótese do Agenda-Setting, que propõe um modelo explicativo que, quanto maior a ênfase e a continuidade de circulação em um determinado tema nos meios de comunicação, maior é a importância que o público atribui a esse assunto em sua agenda. Verifica-se nesta análise que quanto mais informações sobre o assunto são veiculadas, maior a possibilidade dos telespectadores incluí -los nos debates públicos e políticos sobre o tema. Diante desse contexto, este capítulo aprofunda-se fazendo um breve histórico e expondo conceitos dentro desse quadro referencial.

Para o início deste debate, é interessante começar com a ideia geral de Ramonet (1999), que considera que a televisão ocupa um lugar de destaque na sociedade, pois dita normas e de certa forma obriga os demais meios a tomá-la como exemplo. Nesse sentido, Arbex (2001) defende que a televi- 
são é um pólo de seleção e divulgação das notícias, assim como de comentários e interpretações que delas são feitas. Para o autor, a televisão tem o poder de interferir nos acontecimentos. Isso ocorre porque a televisão tem a capacidade de influenciar a sociedade, ditando o que será ou não um acontecimento público e/ou político.

No rastro dessa configuração está a Hipótese do Agendamento que explica sobre a capacidade de agendamento que os meios de comunicação têm sobre os temas nos debates públicos. Em linhas gerais, esse conceito surgiu como uma ruptura do paradigma funcionalista ${ }^{13}$ sobre os efeitos de comunicação. Sousa (1999) explica que estava presente nos Estados Unidos uma noção que a Comunicação Social não seria capaz de influenciar a sociedade já que os indivíduos relativizariam os impactos causados pela divulgação dos acontecimentos. Mas o agendamento, ao contrário, propõe a existência de efeitos diretos e visíveis sobre a população e explica que, quanto maior for a ênfase e a continuidade de um determinado tema nos meios de comunicação, maior é a importância que o público atribui ao tema em sua agenda de discussão.

A hipótese foi uma das suposições levantadas pela Teoria Crítica desenvolvida na Escola de Frankfurtt ${ }^{14}$, na Alemanha. Uma teoria, que teve sua origem em 1937, com a publicação de um ensaio-manifesto de Max Horkheimer, chamado "Teoria Tradicional e Teoria Crítica". De acordo com Honnet (1999), a obra de Horkheimer deu início a uma corrente de pensamentos críticos e interdisciplinares que pressupunha a superação da fissura entre a pesquisa empírica e filosófica. Com o passar dos anos, essa teoria teve outros colaboradores, como Theodor Adorno, Walter Benjamin, Herbert Marcuse e Jürgen Habermas. Mas é importante destacar que, apesar disso, nenhum deles podem ser comparados em suas orientações teóricas e nem em relação as posturas temáticas, pois o que os une, ainda conforme Honnet (1999), é uma diretiva geral do pensamento.

\footnotetext{
13 De acordo com Mattelart e Mattelart (2002), o funcionalismo concebia as mídias como mecanismos decisivos de regulação da sociedade e, nesse contexto, só podiam advogar uma teoria voltada para a reprodução de valores do sistema social, do estado de coisas.

14 Fadul (1978) diz que Escola de Frankfurt não existiu, mas sim o Instituto de Pesquisas Sociais da Universidade de Frankfurt. De acordo com Ortiz (1985), as análises desse instituto são sobre um mundo desencantado. Os estudos enfatizam, principalmente, os elementos de racionalidade do mundo moderno para denunciá-los como uma nova forma de dominação.
} 
Segundo Mattlert (2002), a elaboração da Teoria Crítica ocorreu mediante a um cenário intelectual fértil para a criação de uma teoria que crítica o conformismo de uma sociedade diante do autoritarismo. Com a subida de Hitler ao poder, o Instituto de Pesquisas Sociais de Frankfurt foi obrigado a fechar e só abriu novamente em 1950. De acordo com Wolf (2003), os seus representantes principais tiveram que migrar, primeiramente para Paris e depois para as várias universidades americanas.

Max Horkheimer e Theodor Adorno, por exemplos, foram para a Universidade de Colúmbia, nos Estados Unidos. Lá, desenvolveram pesquisas que criticavam o poder vigente na Europa. O ambiente era favorável a esses estudos, como mostra Honnet (1999), pois nos EUA havia um clima intelectual, uma burguesia rica e receptiva, diversos fóruns da vida cultural fervilhavam pelo país, além de ter uma localização geográfica capaz de atrair cientistas de diferentes disciplinas e que também oferecia facilidades institucionais para que os cientistas trabalhassem juntos. Todas essas características contribuíram no desenvolvimento de uma teoria que buscava compreender, principalmente, como as pessoas tornavam-se insensíveis diante à dor no autoritarismo e, com isso, negavam a sua própria condição de indivíduo ativo na sociedade.

Por meio de um estudo interdisciplinar, em que faz críticas à fragmentação da Ciência em setores, a Teoria Crítica recorre à dialética's de Karl Marx para explicar o funcionamento da sociedade e da formação de classe, assim como à psicanálise para entender a formação do indivíduo enquanto componente da sociedade. Em um comportamento crítico nos confrontos com a Ciência e a cultura, pois pretendia evitar a reprodução ideológica das mesmas, a Teoria Crítica apresenta uma proposta política de reorganização da sociedade, de modo a superar o que eles chamavam de "crise da razão".

A razão, sob o prisma dessa teoria, nada mais era que um elemento de conformidade e de manutenção do status quo. Por isso, essa racionalidade precisava ser urgentemente revista por meio de estudos e pesquisas. $O$ maior objetivo da Teoria Crítica era criar sociedades e organizações livres da dominação, em que todos pudessem contribuir e desenvolver-se. Assim como no marxismo, ela faz a compreensão dos fenômenos estruturais da sociedade_como a formação do capitalismo e a industrialização_ por meio

15 Segundo Marconi e Lakatos (1999), a dialética fornece as bases para uma interpretação dinâmica e totalizante da realidade. 
de uma crítica à economia política, buscando na divisão de classes os elementos para explicar a concepção do contexto social, como o desemprego, o terrorismo e o militarismo.

As disciplinas setoriais desviariam esse entendimento da sociedade como um todo e, consequentemente, as pessoas ficavam submetidas à razão instrumental e ao próprio status quo, desempenhando com isso, uma espécie de função de manutenção das normas sociais. Por isso é fundamental, sob o ponto de vista da Teoria Crítica, a utilização de todas as disciplinas de pesquisa da Ciência Social para a elaboração de uma teoria materialista da sociedade capaz de superar o purismo teórico do materialismo histórico e ser, ao mesmo tempo, uma fusão fecunda entre a Ciência Social acadêmica e a teoria marxista.

Com essa visão interdisciplinar e não fragmentada, a Teoria Crítica faz uma análise sobre a mídia. Esses estudos defendem que a produção cultural era tratada como uma mercadoria. Por isso, era bastante cética em relação à informação divulgada pelos veículos de comunicação. Segundo Mattelart e Mattelart (2002), foi na década de 40 que Theodor Adorno e Max Horkeimer criaram o termo indústria cultural para essa forma de abordagem dos veículos de comunicação caracterizada, principalmente, pela ubigüidade, repetitividade e estandardização.

Sobre esse cenário negativo, principalmente, em relação ao conteúdo audiovisual, Oliveira (2007) lembra que a televisão colecionou ao longo das décadas severas críticas sendo o principal artífice da indústria cultural. A expressão publicada em 1947 na Dialética do lluminismo ${ }^{16}$ veio a substituir inclusive a cultura de mass $a^{17}$, que era empregada para denominar, de acordo com Benjamin (1973), os produtos artísticos tecnicamente reproduzidos.

Com isso, o trabalho autônomo da arte era consequentemente destruído, assim como a aura que os elevava à relíquia sagrada do mundo profano do observador. Adorno e Horkeimer tratavam os meios técnicos, como o cinema, o rádio e a fotografia da mesma forma que as fábricas de automóveis. Para eles eram capazes, de acabar com o produto artístico e, ao mes-

16 A tese central da "Dialética do Iluminismo", de Max Horkeimer e Theodor Adorno, é que o projeto iluminista original foi um mito que levou a humanidade a um impasse, no qual a Ciência está a serviço da opressão. Em vez de libertar os homens, trouxe o potencial de destruição em massa.

17 Para Morin (1977), a cultura de massas segue as normas capitalistas e é destinada a um aglomerado de indivíduos compreendidos além das estruturas internas da sociedade. 
mo tempo, expor o público a uma visão remota devido à sua serialização e padronização.

$\mathrm{Na}$ visão desses sociólogos, os resultados produzidos pela indústria cultural eram catastróficos. Os produtos culturais eram entendidos como formas de impedimentos à atividade mental do espectador não passando assim, de produtos alienantes ${ }^{18}$ que contribuíam para uma cultura de alienação. A mídia era vista, por eles, como uma mera reprodutora das relações de força do aparelho econômico e social que, por meio de mensagens ideológicas, anulava a individualidade e a ideia de resistência da audiência. $O$ indivíduo não passava de um fantoche manipulado pelas normas sociais que não tinha capacidade de decidir. Ao falar da televisão, na década de 60, Adorno (1987) defende que ela seguia o esquema industrial

O próprio meio de comunicação, contudo, insere-se no âmbito do esquema abrangente da indústria cultural e, enquanto combinação de filme e rádio leva adiante a tendência daquela, no sentido de cercar e capturar a consciência do público por todos os lados. A televisão permite introduzir furtivamente na duplicata do mundo aquilo que se considera adequada ao real.(Adorno,1987, p.346)

Foi em meio a essas abordagens e estudos da Teoria Crítica que foi levantada, em 1968, uma hipótese elaborada em forma suscetível de pesquisa por Maxwell E. McCombs e Donald Shaw no final da década de 60 (WOLF, 2003) durante um estudo sobre os efeitos da mídia na campanha eleitoral para a Presidência dos Estados Unidos de 1968. O estudo exploratório foi realizado na Universidade da Califórnia, na Carolina do Norte. Durante 24 dias, antes das eleições presidenciais, McCombs e sua equipe aplicaram nos eleitores cem questionários, de diferentes níveis econômicos, sociais e racial, que ainda estavam indecisos em quem votar. Se seria no candidato Humbert ou em Richard Nixon.

Para comparar a agenda do público com a mídia, foram escolhidos cinco jornais, dois canais de televisão e duas revistas semanais. Por meio de análises, contatou-se que a mídia havia influenciado o eleitor, ou seja, os temas abordados pela mídia pautaram os assuntos sobre os quais a população discutia. De acordo com Cohen (1966), a mídia diz não o que pensar, mas em

18 Os meios de comunicação de massa eram vistos como meros reprodutores das relações de força do aparelho econômico social que, por meio de mensagens ideológicas, anulavam a individualidade e a ideia de resistência da audiência (LIMA, 1982). 
que pensar. O pressuposto fundamental dessa hipótese é que a compreensão que as pessoas têm da realidade social é fornecida, em grande parte, pelos mídia.

Wolf (2003) argumenta que, independente de ser notícia ou não, o que os veículos mostram passa a fazer parte do cotidiano das pessoas. Ou seja, o público organiza os seus interesses a partir do que acompanhou na mídia. Sobre esse agendamento, Hester (1980) esclarece que existe ainda uma hierarquização dos fatos veiculados capaz de definir exatamente o que as pessoas assistem, discutem e inserem em suas atividades corriqueiras a tal ponto que, se a informação não for veiculada, a maioria do público fica sem meios para obter esse conhecimento.

Os efeitos dessa relação mídia-receptor foram complementados em 1976 por McCombs. Ele atrelou essa noção de hierarquização dos assuntos divulgados às variáveis ligadas ao tema e ao público. Para McCombs, o consumo de informações e o seu agendamento dependeriam também da necessidade do receptor em obter uma determinada informação. Ou seja, quanto maior fosse o interesse por um tema divulgado pela mídia, maior o impacto dele nas discussões. Levando-se em conta esse conceito, entendese que quanto mais a CT\&I forem divulgadas pela televisão, maiores são as chances desses assuntos integrarem as agendas públicas e políticas. Para este trabalho, quando isso ocorre contribui para o processo de formação do indivíduo enquanto ser social pertencente a uma comunidade e que precisa se sentir inserido nela, cumprindo dessa forma seu papel social (MARQUES DE MELO, 1985).

É importante ainda diferenciar que o agendamento é uma hipótese e não uma teoria por ser uma experiência, um caminho inacabado a ser comprovado. Os sociólogos adotaram essa terminologia, pois caso a perspectiva teórica não tivesse êxito no desenvolvimento da pesquisa, ela não ficaria comprometida e nem invalidada. Apesar de existirem estudos desenvolvidos sobre os efeitos sociais midiáticos, Sousa (1999) afirma que ninguém respondeu definitivamente qual a influência que os meios jornalísticos excercem sobre a população, o que reforça o avanço desta perspectiva e não descarta a possibilidade que esse conceito esteja imbuído nas notícias de CT\&l, já que as notícias dizem sobre o que pensar. Vizeu (2000) destaca que isso ocorre tanto em relação à seleção de objetos que despertam a atenção como a seleção de enquadramentos para pensar esses objetos. 
O TELEJORNALISMO REGIONAL COMO ESPAÇO PRIVILEGIADO PARA A DIVULGAÇÃO CIENTÍFICA

\section{O TELEJORNALISMO REGIONAL COMO ALTERNATIVA PARA A DIFU- SÃO DE PESQUISAS LOCAIS}

O decreto lei 52.795, de 31 de outubro de 1963, prevê que as emissoras de televisão enquanto prestadoras de serviço público precisam dedicar-se pelo menos cinco por cento de seu tempo diário de programação ao serviço noticioso. Esse decreto foi estabelecido há 13 anos depois do surgimento ${ }^{19}$ dos telejornais, mas mesmo assim, o telejornalismo não deixa de ser visto como uma maneira de atender a essa determinação da lei. É preciso atentar-se ainda para o contexto que os telejornais estão inseridos que o fazem relevantes enquanto meio de notícias.

Cádima (1995) assinala que os noticiários são a principal ou as únicas fontes de informações sobre a realidade do mundo contemporâneo para o grande público. Nesse sentido, o discurso dos telejornais seria legitimador de uma nova ordem do mundo percebida por meio da televisão. No Brasil, Vizeu (2000) reforça essa relevância do papel do jornalismo televisivo. Já que a leitura é ainda um fator de exclusão social. Para o autor, o telejornalismo é um bem social, pois nele o mundo é recontextualizado. Por isso, quando se pensa em popularização do conhecimento científico, o telejornalismo segundo Gomes, I.M.A.M. (1995) é um dos caminhos mais viáveis, para não dizer o único, principalmente, o telejornalismo regional como veremos a seguir.

As características e conceitos do telejornalismo o fazem diferente dos demais veículos de comunicação e, ao mesmo tempo, o torna um espaço promissor de informação para o grande público. O texto, som e imagem são grandes aliados nesse sentido, pois aproximam a notícia à realidade do telespectador. Por meio desses elementos, o publico consegue compreender a notícia de modo mais fácil e rápido. E é dessa forma que o material jornalístico é pensado, ou deveria ser produzido. A informação precisa ser absorvida instantaneamente, sem muito esforço, já que o telespectador não pode voltar a assistir a mesma notícia, caso não entenda, como no jornal impresso e na web.

Diante dessas características, Soares (2002) define o telejornalismo como um sistema televisivo que utiliza tecnicamente os recursos eletrônicos para a divulgação de informações no qual seria o ponto de interseção entre o jornalismo (como processo de produção e transmissão de informações) e

19 No dia 18/09/1950 pelo canal 6 de São Paulo, a TV Tupi deu início à história da televisão no Brasil. 
a televisão (como veículo de comunicação de massa). Em uma configuração mais atual, a convergência midiática aproxima-se como um novo horizonte de possibilidades comunicacionais baseadas na rapidez e interatividade.

Soares (2000) diz que o jornalismo televisivo estrutura-se dentro da mídia eletrônica como um campo que tem a pretensão de mostrar os acontecimentos, mas que independente da forma como é feito, esse processo de apresentação jornalística estabeleceu-se como um gênero televisivo no mundo inteiro. Em outra perspectiva, Machado (2000) conceitua o telejornalismo como uma colagem de depoimentos e fontes em uma sequência, e defende que essa montagem não forma um discurso unitário e lógico a ponto de ser compreendido pelo telespectador como algo verdadeiro, pois coloca em choques diferentes enunciados e acaba os relativizando durante sua veiculação.

Mas este trabalho não corrobora com Machado (2000). Para esta pesquisa, o material exibido é "tão mastigado" que em muitos casos o telespectador aceita o discurso como uma verdade. Outro ponto que precisa ser destacado é que nem todos possuem conhecimento qualificado e senso crítico para contextualizar a notícia exibida pelas emissoras e formar uma opinião. Isso sem contar que, não raramente, os telejornais não entrevistam pessoas com visões diferentes sobre um mesmo tema induzindo, em muitos casos, o telespectador a uma percepção unilateral e fabricada sobre os fatos. Wolfer (1982, p. 68) diz ainda que "os telejornais, além de expressarem seu compromisso com informações sobre o que aconteceu e com ideias dominantes no plano social, informam, também sua ideologia”. Sobre isso, Serra (1993) entende que o discurso de um telejornal não é apenas uma transferência de modelos ideológicos ou de conceitos linguísticos, pois o telejornal enuncia.

Apesar dos gargalos na comunicação do jornalismo televisivo, Lacy Andrade (2004) é categórico ao afirmar que as notícias sobre C\&T se resumem em reportagens exibidas nos telejornais diários. Coutinho e Mata (2010) reforçam a ideia de que atualmente o telejornalismo é o principal meio de informação dos brasileiros, tanto em nível local quanto nacional. Mas enquanto bem público ${ }^{20}$, este trabalho verifica que poderiam contribuir mais para a Compreensão Pública da Ciência já que é um importante canal de acesso às informações científicas do grande público.

20 A expressão de Vizeu explica que os conteúdos dos telejornais tem uma universalidade que atinge aos cidadãos, de forma a permitir um acesso mais igualitário ao conhecimento. 
É preciso lembrar ainda que além do caráter informativo, a divulgação do conhecimento científico deveria exercer uma função educativa. A abordagem da Ciência no telejornalismo deve ser considerada uma ferramenta cognitiva de formação de cidadãos mais atualizados e preparados para os desafios do cotidiano. Olutra constatação em relação ao telejornalismo regional é que ele seja um espaço de divulgação científica de pesquisas e estudos locais ainda mais amigáveis, se comparado aos telejornais nacionais. Isso ocorre porque as matérias locais não precisam "competir" com as outras regiões do país, não precisam do crivo da equipe de rede ${ }^{21}$ para ser veiculadas e podem ter frequência e espaço maiores na programação local devido à baixa concorrência.

O Telejornal Regional, fonte de estudo desta dissertação, é definido por Soares (2002) como um trabalho jornalístico em televisão praticado nas emissoras afiliadas das redes nacionais e que transmitem a programação para uma determinada região. Ele é produzido e exibido pelas afiliadas. Segundo Paternostro (1999, p.135), são como "as emissoras de TV que transmitem a programação da emissora principal de uma rede de emissoras. Elas têm normas estabelecidas e seguem a programação original, mas podem, normalmente, produzir programação própria." Embora haja esse conceito, Cruz (1996, p.160) lembra que "não existe dentro da legislação brasileira sobre a radiodifusão nenhuma definição do que seja televisão regional”. Para a autora, a principal dificuldade em definir a televisão regional é estabelecer uma relação direta entre o alcance das ondas de TV e as regiões.

Bazi (2001, p.16) tenta resolver esse impasse conceitual propondo que a televisão regional seja compreendida como "aquela que transmite seu sinal a uma determinada região e que tenha a sua programação voltada para ela mesma". Dentro dessa abordagem, Bazi (2001, p.12) assinala que a "Constituição Federal, promulgada em 1998, em seu artigo 221, inciso III, já previa a regionalização da produção cultural, artística e jornalística das emissoras de televisão, mas ainda faltam as leis ordinárias para regulamentar sua implementação". Depois deste estudo aprofundar-se nesse assunto, também se constatou que apesar de diversos debates realizados com especialistas em comunicação a respeito dos projetos existentes no Congresso sobre renovações de canais, regionalização, fiscalização, entre outros temas, de fato

21 A responsável pela produção e exibição dos assuntos veiculados nos telejornais de rede nacionais. 
não houve avanços significativos nessa área.

Uma outra questão a ser pensada em relação à divulgação científica nos telejornais regionais é a quantidade e a qualidade de matérias exibidas de CT\&l. Para Alberguini (2007),

A importância da Compreensão Pública da Ciência é um fato incontestável na atualidade e a cobertura da mídia reflete essa tendência. Mesmo com a pouca expressividade de programas de Divulgação Científica na televisão no Brasil, principalmente de produção nacional, é possível avaliar que o telejornalismo tem aberto espaço para temas científicos. (ALBERGUINI, 2007, p. 71)

Diante disso, surgem questionamentos a ser levados em consideração na percepção da divulgação científica nos telejornais regionais. Será que a exposição de assuntos relacionados à Ciência nos telejornais, citado por Alberguini (2007), acontece tanto nos veiculados em rede quanto nos regionais e locais ${ }^{22}$ ? E mais, será que isso ocorre na mesma proporção? Observa-se que a exibição de notícias sobre a Ciência nos telejornais nacionais cresceu, mas em contrapartida não se verifica a mesma frequência, tempo de exibição e forma de abordagem nos noticiários regionais. Salcedo e Gomes (2008) analisam que se

Existe pouco espaço para a reflexão crítica, por parte do telespectador, e quando se trata de informação científica, percebe-se sua alienação e aculturação científica. Tal situação acaba por excluir o telespectador de assuntos importantes voltados à melhoria de sua qualidade de vida. Sem divulgação não há impacto e os indivíduos persistem na sua ignorância por não possuírem acesso ao contínuo processo de fazer Ciência. (SALCEDO E GOMES, 2008, p.3)

De acordo com Marcondes Filho (1986), as características de padronização e superficialização da notícia na TV, utilizando de apelos estéticos e emocionais, são responsáveis pelo aparecimento de algumas dúvidas em relação à forma como os avanços da Ciência são narrados. Observa-se também que os padrões do telejornalismo impostos sobre a Ciência, principalmente nos telejornais regionais, onde as equipes de jornalismo são mais reduzidas

22 Segundo Caparelli (1982), os telejornais locais são aqueles produzidos na mesma área de emissão do canal enquanto os regionais são produzidos em parte de penetração do canal. 
e nem sempre os profissionais são qualificados para abordar o assunto, o tema é eliminado na maioria das vezes do jornal. $E$ isso acontece desde o início da produção, na seleção da notícia, até a sua exibição.

Nesse sentido, Melo e Gomes (2010) explicam que a Ciência só vira notícia quando está associada às questões factuais, dando ênfase sempre aos assuntos que chamam a atenção do público pela polêmica. E quando o telejornalismo apropria-se do discurso científico, apresenta um novo discurso que já não é original do cientista, fonte da informação. Essa mediação passa por critérios de valor e sentido, por mudanças de linguagens e de outras estratégias usadas para "facilitar" a compreensão e seduzir o grande público que, muitas vezes, ocasiona em distorcer a informação passada pelo pesquisador. Esses conflitos entre o mundo científico/ acadêmico e o jornalismo, principalmente o televisivo que lida com desafios diários como a necessidade de imagem para compor a matéria e a rapidez para colocar a notícia no ar apontam para a necessidade de repensar a forma de produção da notícia e suas mediações com a CT\&l.

\section{CONSIDERAÇÕES FINAIS}

No Brasil, a divulgação científica vem ganhando espaço na agenda pública, mas quem recorre aos telejornais regionais como única fonte para obter informações sobre a CT\&I fica pobremente informado sobre o assunto. Este trabalho serve como alerta, principalmente, como fonte de reflexão para jornalistas, pesquisadores e o público em geral. Para este trabalho, é preciso criar um espaço rotineiro de divulgação científica nos telejornais, como quadros ou colunas, para que o tema tenha uma chance mais promissora de ir ao ar nos noticiários locais.

Existe um descompasso entre o jornalismo e a Ciência que está inerente à rotina da profissão. O tempo dos jornalistas é diferente dos pesquisadores. Enquanto os profissionais da notícia lutam para conseguir chegar com a matéria a tempo de ser inserida no telejornal, os cientistas não se sentem pressionados com essa "correria". Ao contrário, muitas vezes, percebem que a pressa pode induzir ao erro.

Para este estudo não existe como equalizar frequências de origens e essências tão distintas, mas percebe-se que o interesse em promover a divulgação científica pode unir fazeres tão distintos. Esta pesquisa sugere que as instituições de pesquisa estimulem a divulgação por meio de homenagens e 
premiações internas para que tanto jornalistas quanto pesquisadores sejam estimulados à difusão do assunto.

Todas as camadas da sociedade devem acumular esforços para ampliar as vozes da Ciência. Como sugestão, propõe-se a elaboração de um Guia de Fontes para as instituições de pesquisa. Assim, os jornalistas podem selecionar os entrevistados de acordo com suas necessidades e ampliar o leque de entrevistados para os telejornais. Em suma, nesse livro teria os contatos dos pesquisadores (nome do pesquisador, graduação, especialização, mestrado, doutorado, telefone de contato, e-mail e área de conhecimento) para que os meios de comunicação façam matérias e divulguem para população. O índice seria organizado por temas e assuntos de interesse. Dessa forma, este estudo espera que a facilidade e a diversidade de fontes animem os jornalistas a fazerem a divulgação científica.

Por fim, em vez de encerrar com algo conclusivo, corroborando com a própria essência da Ciência que é muito mais questionadora, termina-se este capítulo convidando a todos a refletirem sobre as seguintes questões:

(a) Os jornalistas e pesquisadores precisam repensar em novas formas de trabalho e relacionamento. As rotinas e as organizações de trabalho eliminam, muitas vezes, a CT\&I dos telejornais;

(b) Cabe ao público participar dessa tarefa de cobrar das afiliadas informações sobre o que acontece nas universidades e instituições de pesquisa. Afinal, as emissoras são concessões públicas e as pesquisas são pagas com o dinheiro da população.

(c) O Estado precisa criar Políticas Públicas que incluam a CT\&l em telejornais. Não adianta colocar o assunto em programas com horários que a maioria das pessoas não assiste. Os noticiários são interessantes para esta pesquisa, entre outros motivos, porque atingem um público de massa, são espaços privilegiados de formação de identidades, de construção e interpretação da realidade e têm incidência sobre as agendas públicas e políticas.

\section{REFERÊNCIAS}

ADORNO, Theodor. A Indústria Cultural. In: COHN, Gabriel (Org). Comunicação e Indústria Cultural. 5 ed. São Paulo: T. A. Queiroz, 1987.

AGUIAR, Leonel de Azevedo. Critérios de noticiabilidade no jornalismo investigativo: um estudo preliminar. In: XXIX CONGRESSO BRASILEIRO DE CIÊNCIAS DA COMUNICAÇÃO, 29., 2006, Brasília. Anais... São Paulo: Intercom, 2006. Disponível em:<http://www.port- 
O TELEJORNALISMO REGIONAL COMO ESPAÇO PRIVILEGIADO PARA A DIVULGAÇÃO CIENTÍFICA

com.intercom.org.br/pdfs/15664601413775691653941453872101550614.pdf >. Acesso em: 10 out. 2012.

ALBERGUINI, A.C. A Ciência nos Telejornais Brasileiros (O papel educativo e a compreensão pública das matérias de CT\&I). 2007. 300 f. Tese (Doutorado em Comunicação Social)- Programa de Pós-Graduação em Comunicação Social da Umesp, Universidade Metodista de São Paulo, São Bernardo do Campo, 2007.

ARBEX, J.J. Showrnalismo: a notícia como espetáculo. SP: Casa Amarela, 2001.

AUTHIER-REVUZ, Jacqueline. Palavras incertas: as não do dizer. In: Coleção Repertórios. São Paulo: Editora da Universidade Estadual de Campinas UNICAMP, 1998.

BARROS, Henrique Lins de. Museus e Ciência. In: SOUZA, C.M.; Marques, N.P.; Silveira, T.S. (Org.). A Comunicação Pública da Ciência. Taubaté (São Paulo): Cabral Editora e Livraria Universitária, 2003.

BOBBIO, Norberto. A Era dos direitos. Rio de Janeiro: Campus, 1992.

. O futuro da democracia. 6. ed. Rio de Janeiro: Paz e Terra, 1986.

BOURDIEU, Pierre. Para uma sociologia da Ciência. $2^{a}$ ed. Lisboa: Ática, 2008.

BOSI, Alfredo Dialética da colonização. 3.ed. São Paulo, Companhia das Letras, 2000.

CÁDIMA, Francisco Rui. O fenômeno televisivo. Lisboa: Círculo de Leitores, 1995.

CALVO HERNANDO, Manuel. Educación y comunicación, un doble desafio de nuestro tiempo, 2004. Disponível em <http://www.manuelcalvohernando.es>. Acesso em: 10 dez. 2006.

CAPARELLI, Sérgio. Televisão e capitalismo no Brasil. Porto Alegre: LP\&M, 1982.

CARACA, João. A Comunicação em Ciência. In: SOUZA, C.M.; MARQUES, N.P.; Silveira, T.S. (Orgs.). A Comunicação Pública da Ciência. Taubaté, São Paulo: Cabral Editora e Livraria Universitária, 2003.

CARAÇA, Bento Jesus. A cultura Integral do Indivíduo: problema central do nosso tempo. In ___ Conferências e outros escritos. Lisboa: Tipografia Antonio Coelho Dias, 1978.

COHEN, B.C. The press and foreign policy. In BERELSON, B.R; JANOWITZ, M. (Orgs.). Reader in Public Opinion and Communication. NY: The Free Press, 1966.

CRUZ, Dulce Márcia. Televisão e negócio, a RBS em Santa Catarina. Florianópolis: UFSC, 1996.

FADUL, Anamaria. Indústria Cultural e Comunicação de Massa. Disponível em: <http:// www.crmariocovas.sp.gov.br/pdf/c_ideias_17_053_a_059.pdf>. Acesso em: 22 out.2012.

FERREIRA, Aurélio Buarque de Holanda. Novo dicionário Aurélio da língua portuguesa. Rio de Janeiro: Positivo, 2004.

FLEURY, Sonia. A expansão da cidadania. In: VII CONGRESO INTERNACIONAL DEL CLAD SOBRE LA REFORMA DEL ESTADO Y DE LA ADMINISTRACIÓN PÚBLICA, Lisboa, Portugal, 8-11, 2002. 
GOMES, I.M.A.M; SALCEDO, D.A.; ALENCAR, L.B.. O jornal nacional e a ciência. Intexto. Porto Alegre: UFRGS, v.1, n.20, p. 15-33, janeiro/ junho 2009. Disponível em:<http://www. seer.ufrgs.br/index.php/intexto/article/download/8413/6025>. Acesso em: 21 set. 2010.

GUIMARÃES, Eduardo (org). Produção e circulação do conhecimento: estado, mídia e sociedade. Campinas, Pontes Editores, 2003.

HONNETH, A. Teoria crítica. In: GIDDENS, A,; TURNER,J. (Org.). Teoria Social Hoje. São Paulo: Editora UNESP, 1999. p. 503-552.

LIMA, Luiz Costa. Teoria da Cultura de Massa. $3^{\text {a }}$ ed, RJ, Paz e Terra, 1982.

MACHADO, A. A Televisão Levada a Sério. São Paulo: Senac, 2000.

MARCONDES FILHO, C. O capital da notícia: o jornalismo como produção social de segunda natureza. São Paulo: Ática, 1989.

MARCONI e LAKATOS, M. A. e E. M. Técnicas de Pesquisa. SP, 1999

MARQUES DE MELO, J. Para uma leitura crítica da comunicação. São Paulo: Edições Paulinas, 1985.

MATTELART, Armand; MATTELART, Michèle. História das Teorias da Comunicação. $2^{\mathrm{a}}$ ed. Campo das Letras: Porto, 2002.

MEDEIROS, R. O conhecimento socializado e o papel do jornalismo no contexto da divulgação da Ciência. In: SOUSA, C. M.; PERIÇO, N. M.; SILVEIRA, T. S. (Orgs.). A comunicação pública da Ciência. Taubaté, SP: Cabral Editora e Livraria Universitária, 2003. p.79-93.

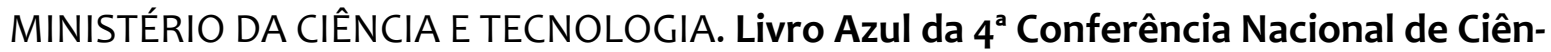
cia, Tecnologia e Inovação para o Desenvolvimento Sustentável. Brasília: Ministério da Ciência e Tecnologia/Centro de Gestão e Estudos Estratégicos, 2010.

MORÁN, José Manuel. A informação na televisão: critérios editoriais. Revista Comunicação e Sociedade. N. 14, 1986. São Bernardo do Campo: Umesp.

MOREIRA, Ildeu de Castro. A Inclusão Social e a popularização da Ciência e tecnologia no Brasil. Inclusão Social, vol.1, n.2, 2006. Disponível em: <http://revista.ibict.br/inclusao/ index.php/inclusao/article/view/29/50>. Acesso em: 25 out. 2012.

MORIN, Edgar. Cultura de massas no século XX: o espírito do tempo. Rio de Janeiro: Fo-rense-Universitária, 1977.

MOTTA-ROTH, D. A popularização da Ciência como prática social e discursiva. In: ENCONTRO DO NÚCLEO DE ESTUDOS AVANÇADOS LINGUAGEM CULTURA E SOCIEDADE, 2009, Santa Maria, Anais... Santa Maria: LABLER-PPGL/UFSM, 2009a.

OLIVEIRA, F. Comunicação pública e cultura científica. Parcerias estratégicas, 13, 2001, p.201-208. Disponível em: <http://ftp.mct.gov.br/CEE/revista/parcerias13/10.pdf>. Acesso em: 02 set. 2011

ORTIZ, Renato. A escola de Frankfurt e a questão da cultura. Piratininga: São Paulo, 1985. Disponível em: <http://www.piratininga.org.br/images/ORTIZ_Renato_A_ESCOLA_ DE_FRANKFURT_E_A_QUESTAO_DA_CULTURA.pdf>. Acesso em: 23 nov. 2012.

PATERNOSTRO, V.I. O texto na TV Manual de Telejornalismo. SP: Campus, 1999. 
PEREIRA, A.; SERRA, I. ; PEIRIÇO N.M. Valor da Ciência. In: SOUZA, C.M.; MARQUES, N.P.; SILVEIRA, T.S. (orgs.). A Comunicação Pública da Ciência. Taubaté, São Paulo: Cabral Editora e Livraria Universitária, 2003.

RAMONET, Ignácio. A tirania da comunicação. Petrópolis: Vozes, 1999.

REIS J. Ponto de vista: José Reis (entrevista). In: MASSARANI, L.; MOREIRA, I. C.; BRITO, F. (Orgs.) Ciência e Público: caminhos da divulgação científica no Brasil. Rio de Janeiro: Casa da Ciência, UFRJ, 2002.

SÁNSHEZ MORA, A. M. A divulgação da ciência como literatura. Tradução: Silvia Perez Amato. Rio de Janeiro: Casa da Ciência, UFRJ, 2003.

SERRA, Heloísa Helena Sá Vale. Os fatos e os telejornais. 1993. Dissertação (Mestrado em Comunicação Social) - Centro de Filosofia e Ciências Humanas, da Universidade Federal do Rio de Janeiro, Rio de Janeiro, 1993.

SOARES, Giselle Silva. Entre o projeto de modernidade e a efetivação da democracia: marcas deixadas na construção da vida social brasileira. Serv. Soc. Soc., SP, n.109, mar.2012. Disponível em: <http://www.scielo.br/scielo.php?script= sci_arttext\&pi$\mathrm{d}=$ S0101-66282012000100003\&lng=en\&nrm=iso>. Acesso em: 06 mar. 2012.

SOARES, M.V.C.S. A origem das notícias no telejornalismo regional: investigação e análise da produção da informação em quatro telejornais de Mato Grosso do Sul. 2002. Dissertação (Mestrado em Jornalismo e Editoração)- Pós-Graduação da Escola de Comunicações e Artes da Universidade de São Paulo, São Paulo, SP, 2002.

SOUSA, Jorge Pedro. As "Teorias" do jornalismo e dos efeitos sociais dos Media Jornalísticos. Universidade Fernando Pessoa, 1999. Disponível em: <http://www.bocc.ubi.pt/ pag/_texto.php?html2=sousa-pedro-jorge-noticiasefeitos. html>. Acesso em: 22 set. 2011.

TORAINE, A. O que é democracia. São Paulo: Edusp, 1996.

VIZEU, Alfredo. As rotinas produtivas dos editores de texto no telejornalismo: decidindo o que é notícia, 2000. Disponível em: <http://www.portcom.intercom.org. br/pdfs/ 088f49b2a1b9142520de3e1dofe1a043.PDF>. Acesso em: 13 jan. 2012.

WOLF, M. Teorias da comunicação. Lisboa: Presença, 2003. 


\section{Bárbara Martins Zaganelli}

Doutoranda em Ciência da Informação no Instituto Brasileiro de Informação em Ciência e Tecnologia (IBICT)/ Universidade Federal do Rio de Janeiro (UFRJ). Mestre em Políticas Sociais pela Universidade Estadual do Norte Fluminense Darcy Ribeiro (UENF). Professora da Universidade Candido Mendes de Campos dos Goytacazes (UCAM RJ).Jornalista há mais de 15 anos, com experiências em afiliadas na Rede Globo e Rede Record. Rio de Janeiro.

\section{Marcelo Carlos Gantos}

Pós-doutoramento na Escuela de Estudios Hispanamericanos na Espanha (EEHA). Doutor em História Social da América pela Universidade Federal Fluminense (UFF). Professor associado do Programa de Pós-Graduação em Politicas Sociais da UENF. Líder da Unidade Experimental de Som e Imagem $(\mathrm{CCH})$ da UENF.Rio de Janeiro. 